\title{
STATUTORY WELFARE MEASURES IN BUILDING CONSTRUCTION INDUSTRIES: A CASE STUDY OF MYSURU CITY
}

\author{
Ananda P \\ Research Scholar, \\ DoS in Social Work, \\ University of Mysore \\ Mysuru, Karnataka, India
}

\author{
Prof. Y.S Siddegowda \\ Dos, in Social Work, \\ University of Mysore \\ Mysuru, Karnataka, India
}

\begin{abstract}
Objective: The present study has attempted to discover the labour welfare measures in building construction industry. Material and Methods: The crosssectional study has conducted. The data collection was done through the Interview schedule. The collected data the researcher has computed in factors analysis. Results and Conclusion: The highest correlation coefficient value is found between toilets and washing facilities and the highest correlation coefficient value is also found between toilets and shelter and accommodation. The KMO value is 0.733and it greater than.0.5. Hence, samples are adequate for factor analysis. The Chi-square test value is $\mathbf{1 6 6 4 . 8 7 7}$ and it is significant at one per cent level. Worker welfare is a very complete term which may include any activity which is attached to the social, moral and economic betterment of workers furnish by any industries.
\end{abstract}

Keywords: Welfare Measures, Building Construction Workers, Building Construction Industries.

\section{INTRODUCTION}

Labour welfare is a term contain various services, benefits and facilities furnished by the employers to the workers for their gain living. (Raj \& Julius, 2017). India's labour policy is based primarily on labour welfare measures and legislation. The labour legislations and improvement policies were also influenced by the important human rights, conventions, and standards that have developed over the years.(Parwez, 2015). The conformity of worker influence is possible only when they divinity fully satisfied with their employer and the working environment on the work.(G.Aarthi, 2018).Labour welfare- raise the health and work are for safety and all-purposive richness and expertise of the specialist passed the base standard, establish by work legislation. (Ulle et al., 2018) Labour welfare may be viewed as a total concept as a social and economic component. The total concept is a desirable state of existence. (Simi, 2014) Labour welfare involving wellbeing, physical, mental, moral and emotional of the workers. Welfare helps in retention the morale and motivation of employees high to retain the employees for a longer period. (Rao, 2017). The statutory schemes are those schemes that are mandatory to provide by an organization as conformity to the laws governing employee health and safety, these include proper and adequate, lighting, canteen facilities, changing rooms, facilities for sitting, drinking water, first aid appliances, latrines and urinals, washing places, spittoons, restrooms..(Tiwari, 2014). Welfare need not be in involving money in the work but in any variety. Labour welfare includes monitoring of working conditions, deed of industrial harmony through infrastructure for health, industrial relations and insurance against disease, accident and unemployment for the workers and their families. (Manasa, 2015).

\section{LITERATURE REVIEW}

(Suresh C. Srivastava, 2017)Work an important place in an industrial society. It is all the more so in a nation likes ours which has board upon com intelligent plans of industrialization. It focuses on conflicting claims and interests of labour and, management. A worker anticipates maximum welfare amenities -when he works in a factory, mine, port and dock or other Industrial organization. On the other hand, the management wants to furnish minimum welfare facilities to the labour.

(Dnyaneshwar, 2018)The study revealed that welfare suggests many ideas, meanings and connotations, such as the state of well-being, health, happiness, prosperity and the development of human resources. The study discussed the concept of welfare has various angles. The study state that welfare has been described as a total concept. The study revealed a desirable state of existence involving physical, mental, moral and emotional well-being. The study found that these four elements together constitute the structure of welfare on which its totality is based.

(Gopalakrishnan, 2017) The study state that the work in the building construction industry is laborious, the construction work includes an extreme of manual or the physical work. The study found that the work in the building construction industry is much dangerous and dirty. The study recommended that good welfare measures help to maintain their health thereby improve their efficiency. The study state that unlike other 


\section{International Journal of Engineering Applied Sciences and Technology, 2020 Vol. 5, Issue 8, ISSN No. 2455-2143, Pages 141-146 \\ Published Online December 2020 in IJEAST (http://www.ijeast.com)}

manufacturing industry, the workplace in the building construction industry is not stable or in a covered place.

(M. Senthilkumar, 2014) the study state that Labour welfare is nothing but the upkeep function of personnel in the sense that it is directed specifically to the safeguarding of worker health and attitudes. The study described that it contributes to the maintenance of worker morale. The study also revealed that the welfare services in an industry are to improve the living and working conditions of workers and their families because the worker's well-being cannot be achieved in isolation of his family.

(Arun Jyothi, 2012)The study states that the welfare measures have more significance in the context of the poor standard of livings of the Indian building construction industries. The study revealed that. It is one major aspect of national programs towards the raise of the welfare of people and is as such designed to create a life and work environment of decent wellbeing for working class.

\section{STATEMENT OF PROBLEM}

This study is significant to ascertain labour statutory welfare facilities adopted in building construction industries

\section{OBJECTIVES OF THE STUDY}

1) To ascertain various statutory welfare facilities provided at various building construction industries.

2) To discovers the employers' seriousness to furnish the welfare facilities to building construction workers.

\section{SCOPE OF THE STUDY}

This study aims to ascertain the view of the building construction workers whether the building construction industries are providing necessary health, safety and welfare measures the extent of the current study named" labour welfare measures" is limited only to selected building construction industries in Mysuru city.

\section{Statutory Welfare Measures}

The preamble to our Indian Constitution promises justice - social, economic and political. It also stresses the Equality of status and opportunity. Article 23 of the constitution prohibits traffic in human beings and forced labour. Article 24 prohibits the employment of children in factories. The article 38 and39 spelt under directive principles of state policy are now enforceable as per the dictums laid by our supreme court. Some of the important Statutory Welfare measures given by the government are as follows:

$>$ Washing Facilities. According to Sec. 42, in every factory: (a) Adequate and suitable washing facilities shall be provided and maintained for the use of the workers therein. (b) Separate and adequately screened facilities shall be provided for the use for male and female workers. (c) Such facilities shall be conveniently accessible and shall be kept clean.

$>$ Facilities for storing and drying clothing. Under Sec. 43 , the state government may in respect of any factory or class or description of factories make rules requiring the provisions therein of suitable places for keeping clothing not worn during working hours and for the drying of wet clothing.

$>$ Facilities for Sitting. According to Sec. 44, in every factory, a suitable arrangement for sitting shall be provided and maintained for all workers obliged to opportunities for rest which may occur in the course of their work.

> First - aid appliances. Under Sec. 45, this shall every factory be provided and maintained to be readily accessible during all working hours. First aid boxes or cupboards equipped with the prescribed contents and the number of such boxes or cupboards to be provided and maintained shall not be less than one for every one hundred and fifty workers ordinarily employed at any one time in the factory.

In every factory wherein more than five hundred workers are ordinarily employed, there shall be provided and maintained an ambulance room of the prescribed size, containing the prescribed equipment and in the charge of such medical and nursing staff as may be prescribed and those facilities shall always be made readily available during the working hours of the factory.

$>$ Canteens. Under Sec. 46, the state government may make rules requiring that in any specified factory wherein more than two hundred and fifty workers are ordinarily

\section{Acts about Labour Welfare Measures as Follows:}

1. The Factories Act, 1948

2. The Employees State Insurance Act, 1948

3. The payment of Wages Act, 1936

4. The Workmen's Compensation Act, 1923

5. The employees ${ }^{\text {ee }}$ provident fund Act, 1952.

6. The Payment of Gratuity Act, 1962

7. The Maternity Benefit Act, 1961

\section{RESEARCH METHODOLOGY}

\begin{tabular}{|c|c|}
\hline $\begin{array}{c}\text { Research } \\
\text { work }\end{array}$ & Empirical Study \\
\hline $\begin{array}{c}\text { Primary } \\
\text { data }\end{array}$ & $\begin{array}{c}\text { Interview method, direct } \\
\text { observation and also by a structured } \\
\text { questionnaire }\end{array}$ \\
\hline $\begin{array}{c}\text { Secondary } \\
\text { data }\end{array}$ & E-journals, E Thesis and websites \\
\hline $\begin{array}{c}\text { Sampling } \\
\text { Methods }\end{array}$ & Stratified Radom Sampling methods \\
\hline
\end{tabular}




\begin{tabular}{|c|c|}
\hline $\begin{array}{l}\text { Sample } \\
\text { area }\end{array}$ & $\begin{array}{l}\text { Mysuru city ( Building construction } \\
\text { Industries Selected Randomly) }\end{array}$ \\
\hline Study & 280 building Construction \\
\hline Population & Industries Selected for the Study \\
\hline Analysis & $\begin{array}{l}\text { SPSS package, Factor Analysis } \\
\text { employed }\end{array}$ \\
\hline $\begin{array}{l}\text { Responden } \\
\text { ts }\end{array}$ & $\begin{array}{l}\text { Building construction workers Male } \\
\text { and female }\end{array}$ \\
\hline $\begin{array}{c}\text { Valid } \\
\text { sampling } \\
\text { Size }\end{array}$ & $\begin{array}{l}360 \text { Building Construction } \\
\text { Industries }\end{array}$ \\
\hline $\begin{array}{l}\text { Scaling } \\
\text { technique }\end{array}$ & 5 point Scale \\
\hline $\begin{array}{l}\text { structured } \\
\text { questionnai } \\
\text { re } \\
\text { Design }\end{array}$ & $\begin{array}{l}1 \text { th - } 6 \text { the questions contain } \\
\text { Demographic Profile of workers. } \\
\text { remaining } 15 \text { questions contain the } \\
\text { opinion of respondents related } \\
\text { welfare furnished in the building } \\
\text { construction workers }\end{array}$ \\
\hline
\end{tabular}

\section{Factor Analysis for Welfare Measures in Building Industries}

\section{Welfare Measures in the Work Place}

The Labour and workers being engaged in building industry have been adopted welfare measures in workplace. In the present analysis, an attempt made to identify welfare measures associated with building industry.

The welfare measures considered for the present study are:

- Toilets

- Drinking-Water

- First-aid

- Cretches

- Preparing Meals in Satisfactory Conditions.

- Facilities Boiling Water

- Canteen

- Sufficient Tables

- Deposit of Protective Clothing used for work

- Storing Clothes

- Washing Facilities

- Shelter and Accommodation

- Changing Rooms and Lockers

The principal component analysis is data reductions techniques which give the combination of factors are jointly contributing to welfare measures in the workplace of labour and workers. The following descriptive statics explain the score for each welfare measures in the workplace in the building industry.

Table: 1.1 Welfare Measures Provided by the Employers (In Numbers and Percentage)

\begin{tabular}{|l|r|r|r|}
\hline Factors & Mean & \multicolumn{1}{|c|}{$\begin{array}{c}\text { Std. } \\
\text { Deviation }\end{array}$} & \multicolumn{2}{|c|}{\begin{tabular}{c} 
Nnalysis \\
\hline Toilets
\end{tabular}} & 4.24 & 1.016 & 360 \\
\hline Drinking-Water & 3.19 & 4.241 .553 & 360 \\
\hline First-aid & 3.58 & 1.348 & 360 \\
\hline Cretches & 4.12 & 1.279 & 360 \\
\hline $\begin{array}{l}\text { Preparing Meals in } \\
\text { Satisfactory Conditions. }\end{array}$ & 4.06 & 1.031 & 360 \\
\hline Facilities Boiling Water & 3.95 & 1.196 & 360 \\
\hline Canteen & 3.75 & 1.411 & 360 \\
\hline Sufficient Tables & 4.04 & .822 & 360 \\
\hline $\begin{array}{l}\text { Deposit of Protective } \\
\text { Clothing used for work }\end{array}$ & 4.13 & .912 & 360 \\
\hline Storing Clothes & 3.95 & 1.368 & 360 \\
\hline Washing Facilities & 3.83 & 1.237 & 360 \\
\hline Shelter and Accommodation & 3.67 & 1.347 & 360 \\
\hline $\begin{array}{l}\text { Changing Rooms and } \\
\text { Lockers }\end{array}$ & 3.91 & 1.377 & 360 \\
\hline \multicolumn{1}{|l|}{ Source: Results arecomputed by } & using primary data \\
\hline
\end{tabular}

Source: Results are computed by using primary data

The scope for factors of each welfare measures is presented in the above table. It has been found from the table that the highest score is found for Toilets and the lowest score was found for Drinking-Water. The standard deviation explains the inconsistency in average score.

From the correlation matrix, it is found that the diagonal matrix is a unit matrix and gives solution for factor analysis. The highest correlation coefficient value is found between Toilets and washing facilities and the highest correlation coefficient value is also found between toilets and shelter and accommodation. It is also proven with many other factors that the correlation coefficient between the factors is other than zero. Therefore, factor analysis is advisable for the present concept welfare measures provided by the employers in the workplace.

Table: 1.2 KMO and Bartlett's Test for Welfare Measure (In Numbers and Percentage)

\begin{tabular}{|l|l|r|}
\hline \multicolumn{2}{|l|}{$\begin{array}{l}\text { Kaiser-Meyer-Olkin Measure of Sampling } \\
\text { Adequacy. }\end{array}$} & 0.733 \\
\hline \multirow{3}{*}{ Bartlett's Test of Sphericity } & Approx. Chi-Square & 1664.877 \\
\cline { 2 - 3 } & df & 78 \\
\cline { 2 - 3 } & Sig. & .000 \\
\hline
\end{tabular}

Source: Results are computed by using primary data

The Kaiser-Meyer-Olkin and Bartlett's tests were conducted to identify the adequacy of the sample for factor welfare measures in building construction industries. The $\mathrm{KMO}$ value is 0.733 and it greater than.0.5. Hence, samples are adequate for factor analysis. The Chi-square test value is 1664.877 and it is significant at one per cent level. Therefore, there are strong relations among the factor in this analysis for identifying the factors jointly being use influences welfare measures in building construction.

Table: 1.3 Communalities for Welfare Measures 
(In Numbers and Percentage)

\begin{tabular}{|l|r|r|}
\hline Factors & Initial & Extraction \\
\hline Toilets & 1.000 & .625 \\
\hline Drinking-Water & 1.000 & .688 \\
\hline First-aid & 1.000 & .736 \\
\hline Cretches & 1.000 & .411 \\
\hline $\begin{array}{l}\text { Preparing Meals in Satisfactory } \\
\text { Conditions. }\end{array}$ & 1.000 & .443 \\
\hline Facilities Boiling Water & 1.000 & .758 \\
\hline Canteen & 1.000 & .636 \\
\hline Sufficient Tables & 1.000 & .522 \\
\hline $\begin{array}{l}\text { Deposit of Protective Clothing used for } \\
\text { work }\end{array}$ & 1.000 & .641 \\
\hline Storing Clothes & 1.000 & .809 \\
\hline Washing Facilities & 1.000 & .719 \\
\hline Shelter and Accommodation & 1.000 & .741 \\
\hline Changing Rooms and Lockers & 1.000 & .598 \\
\hline Extraction Method: Principal Component Analysis. \\
\hline
\end{tabular}

\section{Source: Results are computed by using primary data.}

The communalities for a factor of welfare measures have calculated and found that the initial value the factors are one and extraction factors are other than zero. It indicates that each factor individually and jointly contributes to determining communalities welfare measures. Accordingly, the present factor analysis of the communalities for welfare measures will identify at least one component which represents more than one factor.

Table: 1.4 Total Variance Explained for Factors of Welfare Measures: (In Numbers and Percentage)

\begin{tabular}{|c|c|c|c|}
\hline \multirow[t]{2}{*}{ Component } & \multicolumn{3}{|c|}{ Initial Eigenvalues } \\
\hline & Total & $\%$ of Variance & Cumulative $\%$ \\
\hline 1 & 4.206 & 32.351 & 32.351 \\
\hline 2 & 1.726 & 13.279 & 45.630 \\
\hline 3 & 1.313 & 10.101 & 55.732 \\
\hline 4 & 1.082 & 8.320 & 64.052 \\
\hline 5 & .966 & 7.430 & 71.482 \\
\hline 6 & .917 & 7.052 & 78.534 \\
\hline 7 & .618 & 4.753 & 83.287 \\
\hline 8 & .587 & 4.517 & 87.803 \\
\hline 9 & .427 & 3.286 & 91.089 \\
\hline 10 & .376 & 2.892 & 93.982 \\
\hline 11 & .323 & 2.484 & 96.466 \\
\hline
\end{tabular}

\begin{tabular}{|c|c|c|c|}
\hline 12 & .241 & 1.852 & 98.317 \\
\hline 13 & .219 & 1.683 & 100.000 \\
\hline \multicolumn{4}{|c|}{ Method: Principal Component Analysis. } \\
\hline
\end{tabular}

The Total Eigen value for the factors of welfare measures and percentage of variance explained by each component has been estimated and presented in the above table. Based on the Eigenvalue; four components are extracted for welfare measures. The first components explain 32.351 percent of variation in total variation explained by all the variables. The second components explain 13.279 percent of variations. The third component explains 10.101 percent of variations. The fourth components explain 8.320 percent of the variation. Together four components have explained 64.052 per cent of variations.

\section{Graph 1.5 Scree Plot for Components of Welfare Measures}

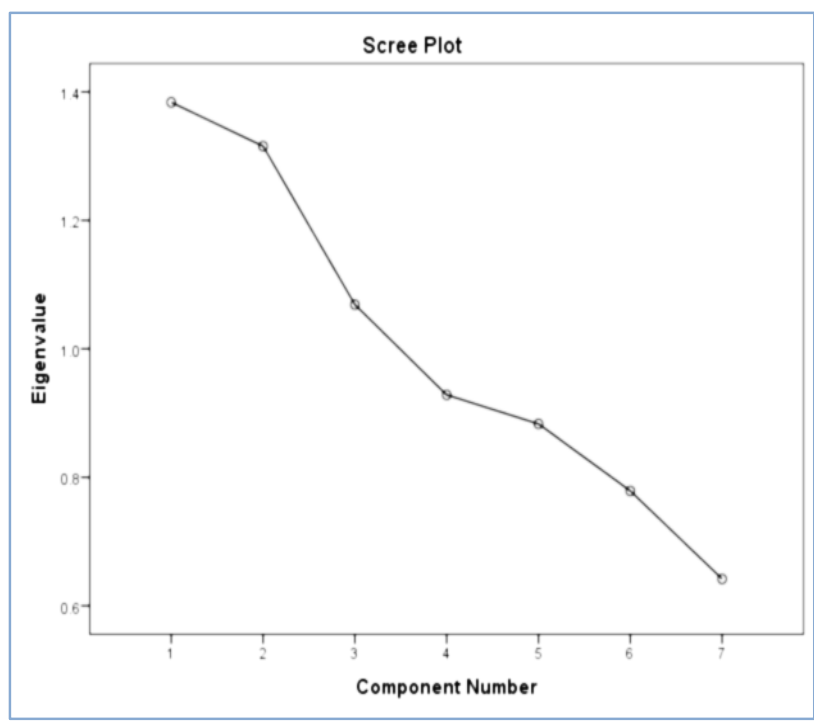

Identification of Factors in Components of Welfare Measures:

Using varimax rotated components matrix of use of welfare measures has identified the specific factors under each component for which values are greater than 0.7 (A factor loading approximately 0.7 is considered to be sufficient).

Table: 1.6 Varimax Rotated Component Matrix for Welfare Measures (In Numbers and Percentage)

\begin{tabular}{|c|c|c|c|c|}
\hline \multirow[t]{2}{*}{ Factors } & \multicolumn{4}{|c|}{ Component } \\
\hline & 1 & 2 & 3 & 4 \\
\hline Toilets & .131 & .005 & $\begin{array}{r}- \\
.770^{-}\end{array}$ & $.124^{-}$ \\
\hline Drinking-Water & .018 & .757 & .142 & .307 \\
\hline
\end{tabular}


International Journal of Engineering Applied Sciences and Technology, 2020

Vol. 5, Issue 8, ISSN No. 2455-2143, Pages 141-146

Published Online December 2020 in IJEAST (http://www.ijeast.com)

\begin{tabular}{|c|c|c|c|c|}
\hline First-aid & .239 & $\begin{array}{r}- \\
.027\end{array}$ & .264 & .780 \\
\hline Cretches & .551 & .281 & .023 & .168 \\
\hline $\begin{array}{l}\text { Preparing Meals in Satisfactory } \\
\text { Conditions. }\end{array}$ & .125 & .620 & $.05 \overline{7}$ & .200 \\
\hline Facilities Boiling Water & .319 & .555 & .586 & .069 \\
\hline Canteen & .088 & .760 & .198 & .363 \\
\hline Sufficient Tables & .328 & .283 & .549 & .182 \\
\hline $\begin{array}{l}\text { Deposit of Protective Clothing used } \\
\text { for work }\end{array}$ & .602 & .025 & .525 & .037 \\
\hline Storing Clothes & .853 & .219 & $\begin{array}{r}- \\
.094\end{array}$ & .158 \\
\hline Washing Facilities & .828 & .121 & .080 & .107 \\
\hline Shelter and Accommodation & .267 & .267 & .200 & .747 \\
\hline Changing Rooms and Lockers & .725 & .119 & .140 & .196 \\
\hline \multicolumn{5}{|c|}{$\begin{array}{l}\text { Extraction Method: Principal Component Analysis. } \\
\text { Rotation Method: Varimax with Kaiser Normalization. }\end{array}$} \\
\hline a. Rotation converged in 5 iterations. & & & & \\
\hline
\end{tabular}

Source: Results are computed by using primary data.

The principal component analysis (PCA) for factors of welfare measures programme has performed and found that factors have shown their intuition for more than one component. Hence, the varimax rotation method has been performed and identified the specific factors for each component.

The PCA has identified the factors for all the three components. At the same time, it is also confirmed that there is no overlapping of factors and components. The first and second components have identified two factors. The other components have identified only one storing clothes and washing facilities between workers are identified under component one. Canteen is identified under component two.

\section{RESULTS AND FINDINGS}

- The study has been found from the table that the highest score is found for toilets and the lowest score was found for drinking-water. The standard deviation explains the inconsistency in average score.

- The highest correlation coefficient value is found between toilets and washing facilities and the highest correlation coefficient value is also found between toilets and shelter and accommodation

- The KMO value is 0.733and it greater than.0.5. Hence, samples are adequate for factor analysis. The Chi-square test value is 1664.877 and it is significant at one percent level. Therefore, there are strong relations among the factor in this analysis for identifying the factors jointly being use influences welfare measures in building construction

- The first components explain 32.351 percent of variation in total variation explained by all the variables. The second components explain 13.279 percent of variations. The third component explains
10.101 percent of variations. The fourth components explain 8.320 percent of variation. Together four components have explained 64.052 percent of variations.

- The principal component analysis (PCA) for factors of welfare measures programme has performed and found that factors have shown their intuition for more than one component. The first and second components have identified two factors. The other components have identified only one storing clothes and washing facilities between workers are identified under component one. Canteen is identified under component two.

\section{SUGGESTIONS}

Building construction industries not established the proper creches to the female workers.

> Building construction industries must install the latrines and urinals for the workers in the working place.

$>$ Canteen facilities are an integral part of the welfare scheme of the workers. Building construction industries must provide the canteen to the workers

\section{CONCLUSION}

The building constructions industries are labouremphasis industries...The welfare facilities give better working conditions and living environment to their workers which as increased team spirit, satisfaction commitment towards the objective of the organization. Worker welfare is a very complete term which may include any activity which is attached with the social, moral and economic betterment of workers furnish by any industries. Welfare facilities like nourishing, drinking water, washing and bathing facility, sanitary and changing rooms, restroom and shelters, facility for cooking meals and eating, temporary housing sheds, transport facility where the shelter is away from the construction site will reduce their fatigue and improve their health.

\section{REFERENCE}

1 Dnyaneshwar, T. S. (2018). A Study of Labour Welfare Facilities Provided to Industrial Workers with Special Reference to Aurangabad and Jalna Industrial Area.

http://shodhganga.inflibnet.ac.in:8080/jspui/handle/10 $603 / 271413$

2 G.Aarthi. (2018). The Study on Impact of Employee Welfare Measures in Automobile Industry. International Journal of Pure and Applied Mathematics, $\quad 118(20), \quad 889-900$. https://acadpubl.eu/hub/2018-118-

21/articles/21a/96.pdf

3 Gopalakrishnan, G. (2017). A study on employee welfare in construction industry. International Journal of Civil Engineering and Technology (IJCIET), 8(3), 6. http://http://www.iaeme.com/ijciet/ 
4 Manasa, B. R. (2015). Employee Welfare MeasuresA Study on Cement Corporation of India Units, in Thandur and Adilabad. International Research Journal of Engineering and Technology (IRJET), 02(09), 8. https://doi.org/Dec-2015

5 M.Senthilkumar. (2014). A Study on Labour Welfare Measures and Industrial Relations in Tamilnadu State Transport Corporation Limited: Villupuram Division [Annamalai Nagar]. http://shodhganga.inflibnet.ac.in:8080/jspui/handle/10 603/45689

6 Parwez, S. (2015). Modified Labor Welfare Measures for Special Economic Zone \& Implications. Indian Journal of Industrial Relations, 10(2), 12.

7 Raj, A. E. A., \& Julius, D. S. (2017). Analysis of Labour Welfare Measures and its Impact on Employee's Commitment. International Journal of Advanced Scientific Research \& Development, 04(05), 12.

8 Rao, D. Y. V. (2017). Need of Welfare Measures in Organization. International Journal of Engineering and Management Research, 7(2), 11.

9 Simi, S. V. (2014). Effectiveness of labour welfare Measures among construction workers In kerala, http://shodhganga.inflibnet.ac.in:8080/jspui/handle/10 603/95799

10 Suresh C. Srivastava. (2017). Labour Welfare and the Law. Journal of the Indian Law Institute, 2(3), 26.

11 Tiwari, D. U. (2014). A Study on Employee Welfare Facilities And Its Impact on Employees Efficiency at Vindha Telelinks Ltd. Rewa (M.P.) India. 3(11), 7.

12 Ulle, R. S., Patil, K., \& Varma, D. A. J. (2018). The Impact of Labour Welfare Measures on Employee Satisfaction. 5(8), 6 . 